\title{
MiR-144 Inhibits Proliferation and Induces Apoptosis and Autophagy in Lung Cancer Cells by Targeting TIGAR
}

\author{
Shanshan Chen ${ }^{\mathrm{a}}$ Ping Li Juan Li ${ }^{\mathrm{a}}$ Yuanyuan Wang ${ }^{\mathrm{b}}$ Yuwen Du ${ }^{\mathrm{b}}$ Xiaonan Chen ${ }^{\mathrm{b}}$ \\ Wenqiao Zang ${ }^{b}$ Huaqi Wang ${ }^{a}$ Heying Chu ${ }^{a}$ Guoqiang Zhao ${ }^{b}$ Guojun Zhanga \\ aDepartment of Respiratory Medicine, the First Affiliated Hospital, Zhengzhou University, Zhengzhou, \\ China, bDepartment of Microbiology and Immunology, College of Basic Medical Sciences, Zhengzhou \\ University, Zhengzhou, China
}

\author{
Key Words \\ Lung cancer cell • MiR-144 • TIGAR • Proliferation • Apoptosis
}

\begin{abstract}
Background: MiRNAs are noncoding RNAs of 20-24 nucleotides that function as posttranscriptional negative regulators of gene expression. MiRNA genes are usually transcribed by RNA polymerase II in the nucleus. Their initial products are pre-miRNAs which have cap sequences and polyA tails. The p53-induced glycolysis and apoptosis regulator (TIGAR) was discovered through microarray analysis of gene expression following activation of p53. However, little is known about the effect of miR-144 on cell proliferation and apoptosis and how it interacts with TIGAR. Methods: We performed real-time PCR, western blotting, CCK8, colony formation, tumor growth, flow cytometry, Caspase3/7 activity, Hoechst 33342 staining, MDC staining of autophagic cells and luciferase reporter assays to detect the influence of miR144 to lung cancer cells. Results: miR-144 targeted TIGAR, inhibited proliferation, enhanced apoptosis, and increased autophagy in A549 and H460 cells. Conclusions: Our study improves our understanding of the mechanisms underlying lung cancer pathogenesis and may promote the development of novel targeted therapies.
\end{abstract}

Copyright $@ 2015$ S. Karger AG, Basel

\section{Introduction}

MiRNAs are noncoding RNAs of 20-24 nucleotides that function as post-transcriptional negative regulators of gene expression [1]. It is now well known that miRNAs regulate the expression of multiple target genes and affect a variety of cellular pathways, specifically in cancer development and progression [2,3]. MiR-144, sharing the same locus with miR-

\begin{tabular}{ll}
\hline Guojun Zhang & Department of Respiratory Medicine, the First Affiliated Hospital of Zhengzhou \\
and Guoqiang Zhao & University, No. 40 Daxue Road, Zhengzhou 450052 (China) \\
and Department of Microbiology and Immunology, College of Basic Medical Sciences, \\
Zhengzhou University, No.100 Kexue Road, Zhengzhou 450001 (China) \\
E-Mail gjzhangzzu@126.com and E-Mail zhaogq@zzu.edu.cn
\end{tabular}




\section{Cellular Physiology and Biochemistry}

Cell Physiol Biochem 2015;35:997-1007

\begin{tabular}{l|l}
\hline DOI: $10.1159 / 000369755$ & (C) 2015 S. Karger AG, Basel
\end{tabular}

www.karger.com/cpb

451[4], has been reported in many cancers. A report from Zhang et al. claimed that miR144 promoted proliferation, migration, and invasion of nasopharyngeal carcinoma through repression of phosphatase and tensin homolog (PTEN) [5]. Sureban et al. also showed that knockdown of doublecortin and CaM kinase-like-1 (DCAMKL-1) increased miR-144 expression, which in turn inhibited epithelial-mesenchymal transition (EMT) of pancreatic cancer [6]. These data impelled us to further study the relative mechanism of miR-144 acting on lung cancer behavior.

Lung cancer is a major cause of cancer-related death worldwide. Although the diagnosis and therapy are in advances and the prognosis is encouraging, the number of cases and deaths related to lung cancer is still rising in many parts of the world. Lung cancer consisted of multiple sequential steps that are not completely understood to date, more investigation of this mechanism is urgently needed. Altered expression of miRNAs has been observed in lung cancer, suggesting that miRNA deregulation plays a role in lung carcinogenesis. For example, miR-145 inhibited lung cancer cell metastasis and EMT via targeting the Oct4 mediated Wnt/ $\beta$-catenin signaling pathway [4]. Lan et al. elucidated that miRNA-15a/16 can enhance radiation sensitivity by regulating the TLR1/NF- $\kappa B$ signaling pathway and act as a potential therapeutic approach to overcome radioresistance for lung cancer treatment [7]. Data from Zha et al. have showed miR-144 exerted direct regulatory roles on Zinc finger $\mathrm{X}$-chromosomal protein (ZFX) expression, which seems to be associated with tumorigenesis [8]. Our previously studies also found that the expression of miR-144 in these tissues was lower than in adjacent, paired non-tumor tissues by a miRNA chip-based expression analysis of lung cancer tissues.

Relevant bioinfomatics were analyzed and we hypothesized that miR-144 interacted with the p53-induced glycolysis and apoptosis regulator (TIGAR). TIGAR was discovered through microarray analysis of gene expression following the activation of p53 [9]. It is a p53-induced gene that can reduce the level of fructose2, 6-bisphosphate in cells, resulting in inhibition of glycolysis, and plays a crucial role in apoptosis $[10,11]$. TIGAR overexpression has been described in several types of tumor. Its expression is increased in primary colon cancer and associated metastases [12], as well as in invasive breast cancer when compared to normal tissue [13]. TIGAR is also overexpressed in glioblastoma [14].

The effect of miR-144 on lung cancer cells and how it interacts with TIGAR remain unknown. In the present study, we observed miR-144 expression levels in tissues from 67 lung cancer patients, and investigated the function of miR-144 in lung cancer cells.

\section{Materials and Methods}

Patients and tissue specimens

A total of 67 cases of lung cancer cases were examined. All specimens were clinically and histologically diagnosed at the First Affiliated Hospital of Zhengzhou University between 2012 and 2013 and they were quick frozen in liquid nitrogen. This study was approved by the Ethics Committee of Zhengzhou University and written consent was obtained from all patients.

\section{RNA extraction}

For lung cancer tissues, if the proportion of lung cancer cells in a tissue section was $>80 \%$ then the frozen block was subjected to RNA extraction. According to the manufacturer's protocol, total RNA was extracted from 67 pairs of snap-frozen cancer tissues and adjacent normal tissues using TRIzol reagent (Invitrogen, CA, USA). For lung cancer cell lines, total RNA was extracted with an RNA Extraction Kit (Qiagen). The integrity of the RNA was evaluated by a Nanodrop ND-1000 (Thermo Scientific, Worcester, USA). The value of $\mathrm{OD}_{260} / \mathrm{OD}_{280}$ is around 1.8 as a criterion of acceptable purity.

Real-time fluorescence quantitative polymerase chain reaction analysis

Quantitative real-time PCR was performed to quantitate miR-144 expression, using SYBR Premix Ex TaqII (Tli RNaseH Plus) (TaKaRa, Dalian, China) in an ABI 7500 fast system (Applied Biosystems, Carlsbad, 


\section{Cellular Physiology and Biochemistry}

Cell Physiol Biochem 2015;35:997-1007

\begin{tabular}{l|l}
\hline DOI: $10.1159 / 000369755$ & (c) 2015 S. Karger AG, Basel
\end{tabular}

www.karger.com/cpb

Chen et al.: MiR-144 Inhibits Proliferation in Lung Cancer Cells

CA, USA). U6 small nuclear RNA (snRNA) for miR-144 or GAPDH for TIGAR was used as an endogenous control. All samples were analyzed three times. The qRT-PCR results were expressed relative to miR-144 expression levels at the threshold cycle (Ct), which were then converted to fold changes $\left(2^{-\Delta \Delta C t}\right)$.

Cell lines and reagents

A549 and H460 human lung cancer cell lines were purchased from American Type Culture Collection (Manassas, VA, USA). Both cell lines were cultured with Dulbecco's Modified Eagle's Medium (DMEM; Gibco, USA), which contained 10\% fetal bovine serum (FBS; Gibco, USA), $100 \mathrm{IU} / \mathrm{ml}$ penicillin and $100 \mathrm{IU} / \mathrm{ml}$ streptomycin, and the cells were incubated at $37^{\circ} \mathrm{Cunder} 5 \% \mathrm{CO}_{2}$ atmosphere.

Transfection with miRNAs

The miR-144 agomir (GMR-miRmicroRNA-144 agomir) and miR-144 scramble were synthesized by Shanghai GenePharma Co. Ltd. UntreatedA549 and H460 cells, growing exponentially, were plated at $2 \times 10^{7} /$ well in $2.5 \mathrm{ml}$ DMEM medium for $24 \mathrm{~h}$ on six-well plates. Once cells reached about $50 \%$ confluence, transfection was conducted. BTX ECM 2001(Nature gene, New Haven, CT, USA) was used in all transfection processes according to the manufacturer's instructions. Each cell line was separated into three groups: the non-transfected blank group (blank); scrambled miR-144 transfected negative control group (scramble); and the miR-144 agomir transfected group (miR-144).

Western blot analysis

The total protein content of cultured cells was extracted using RIPA buffer containing phenylmethanesulfonylfluoride. A BCA protein assaykit (Beyotime, Haimen, China) was used to determine the protein concentration. Proteins were subjected to SDS-PAGE and transferred onto polyvinylidenedifluoride membranes. After blocking with $5 \%$ skim milk for $1 \mathrm{~h}$ at $37^{\circ} \mathrm{C}$, the membrane was incubated with primary antibodies, polyclonal rabbit anti-TIGAR (1:300) (Santa Cruz Biotechnology, Santa Cruz, CA, USA) at $4^{\circ}$ Covernight. To detect autophagy, the markers of autophagic vacuoles, microtubule-associated protein 1 light chain 3 (LC3) and Beclin 1 were used, and so polyclonal rabbit anti-LC3 I and anti-LC3 II (1:200), polyclonal rabbit and polyclonal rabbit anti- Beclin-1(1:300) (Santa Cruz Biotechnology, Santa Cruz, CA, USA) were also incubated at $4^{\circ}$ Covernight. The membranes were washed three times with Tris-buffered saline and Tween 20 (TBST) and incubated with diluted (1:3000) horseradish-peroxidase -conjugated goat anti-rabbit IgG (Santa Cruz Biotechnology) for $1 \mathrm{~h}$ at room temperature. After three washes in TBST, the films of immunoreactive products were scanned using the Super Signal Substrate Western blotting detection system (Pierce, Rockford, IL, USA). An antibody against GAPDH (Santa Cruz Biotechnology) served as an endogenous reference.

Cell growth assay

Cell Counting Kit (CCK8; Dojindo, Japan) was used to measure cell proliferation. Cells were cultured in 96-well plates $\left(100 \mu \mathrm{l} /\right.$ well)in complete DMEM and were maintained in an incubator at $37^{\circ} \mathrm{C}$ and5\% $\mathrm{CO}_{2}$. CCK solution $(10 \mu \mathrm{l})$ was added to each well. Optical density (OD) value was measured daily over four consecutive days at $490 \mathrm{~nm}\left(\mathrm{OD}_{490}\right)$ to estimate viable cell numbers. The assay was repeated in three independent experiments.

\section{Colony formation assay}

Cells were trypsinized, counted and propagated after transfection, and then cultured in six-well plates at 100 cells/well. The number of colonies was counted at 12 daysafter seeding. The colonies formed were stained with crystal violet, and the colonies with $>50$ cells were scored as surviving colonies. This experiment had three replicates.

\section{In vivo tumor growth assay}

Tumor heterotransplantation was performed to investigate tumorigenic ability of miR-144 in vivo. A549 cells transfected with miR-144(miR-144 group) or with scrambled miRNA (scramble group) and A549 cells (blank group) were subcutaneously inoculated into the dorsal flank of 6-week-old female BALB/c nude mice that were purchased from The Laboratory Animal Unit of the University of Zhengzhou. Animal handling and experimental procedures were approved by the Animal Experimental Ethics Committee of the University of Zhengzhou. Each group contained five mice. Tumor size was measured every week for1 month. The mice were killed and tumors were removed, photographed and weighed. Tumor volumes were 


\section{Cellular Physiology and Biochemistry}

Cell Physiol Biochem 2015;35:997-1007

\begin{tabular}{l|l}
\hline DOI: $10.1159 / 000369755$ & (c) 2015 S. Karger AG, Basel
\end{tabular}

www.karger.com/cpb

Chen et al.: MiR-144 Inhibits Proliferation in Lung Cancer Cells

calculated using the following equation: $\left(\mathrm{D} \times \mathrm{d}^{2}\right) / 2$, where $\mathrm{D}$ means the longest diameter and $\mathrm{d}$ means the shortest diameter.

Flow cytometry assay

Cell cycle was synchronized for $24 \mathrm{~h}$ before collection and 20,000 cells were detected per group. The cells were suspended in $500 \mu \mathrm{l}$ binding buffer and $10 \mu \mathrm{l}$ AnnexinV-fluorescein isothiocyanate (FITC) and $5 \mu \mathrm{l}$ propidium iodidewere added for $15 \mathrm{~min}$. All the procedures were done according to the instructions of the FITC Annexin V Apoptosis Detection Kit I (BestBio, Shanghai, China).The cells were analyzed with a FACScan flow cytometer (BD Biosciences) equipped with Cell Quest software (BD Biosciences). Each treatment was carried out in triplicate.

Caspase $3 / 7$ activity assay

Cells from each treatment group were harvested at $48 \mathrm{~h}$ post-transfection and caspase activity was detected by Caspase-Glo 3/7 Assay kit (Promega, Shanghai, China). 100 $\mu$ l Caspase-Glo 3/7 Reagent was added to each well of the plates, followed by 1 min mixing using an IKA MTS4 plate shaker. Plates were incubated at room temperature for $2 \mathrm{~h}$. Absorbance values were measured with a microplate reader at 405 nm (Infinite M200; Tecan, Mannedorf, Switzerland).

\section{Hoechst 33342 staining assay}

Cells in each group were seeded into a 96-well plate after transfection. Hoechst 33342 (Sigma, St Louis, MO, USA) was added to the culture medium at a final concentration of $5 \mu \mathrm{g} / \mathrm{ml}$. The images were recorded on a computer with a digital camera attached to the microscope, and the images were merged by computer. For quantification of Hoechst 33342 staining, the percentage of Hoechst-positive nuclei per optical field (at least 50 fields) was counted. Apoptotic cells showed bright blue fluorescence.

\section{MDC staining of autophagic cells}

Each group of cells was plated on 24-well plates after transfection for $24 \mathrm{~h}$. Exponentially growing cells were treated with $0.05 \mathrm{mM}$ MDC (Sigma) in DMEM at $37^{\circ} \mathrm{C}$ for $10 \mathrm{~min}$. After that, the cells were washed three times with PBS. The images were captured using a fluorescence microscope (Carl Zeiss, Jena, Germany) at an excitation wavelength of $380 \mathrm{~nm}$ and emission wavelength of $450 \mathrm{~nm}$.

\section{Bioinformatics analysis}

miR-144 data of 67 pairs of primary tumors and normal lung tissues were downloaded from The Cancer Genome Atlas (TCGA) website () [15], and analyzed using Multi-Experiment Viewer (MeV) software (version 4.9, http://www.tm4.org/). The fold differences in miRNA expression were compared by paired t-test. The following online software was used to determine putative miR-144 targets: Target Scan 6.2 (http://targetscan.org) and miRanda (http://www.microrna.org/microrna/getGeneForm. do) [16, 17]. The function of TIGAR was investigated by DAVID bioinformatics (http://david.niaid.nih.gov).

\section{Luciferase reporter assay}

The human TIGAR 3'untranslated region (UTR) fragment containing putative binding sites for miR144 were amplified by PCR from human genomic DNA. The mutant TIGAR 3' UTRs were obtained by overlap extension PCR. The fragments were cloned into a pmirGLO reporter vector (Promega, Madison, WI, USA), downstream of the luciferase gene, to generate the recombinant vectors pmirGLO-WT and pmirGLO-MUT.

For the luciferase reporter assay, A539 cells were co-transfected with miRNA (miR-144 agomir or scrambled-miR-144 negative control) and reporter vectors (pmirGLO-WT reporter vectors or pmirGLOMUT reporter vectors), using BTX ECM 2001 electroporator. Luciferase activities were measured with a Dual-Luciferase assay kit (Promega, Madison, WI, USA) according to manufacturer' s instructions at $24 \mathrm{~h}$ post-transfection. Experiments were repeated three times in triplicate.

Statistical analysis

All data are expressed as means \pm standard deviation. Statistical testing was analyzed using SPSS version 17.0 statistical software. The t-test and one-way analysis of variance were used to analyze data. $P<$ 0.05 was the criterion for statistical significance. 


\section{Cellular Physiology and Biochemistry}

Cell Physiol Biochem 2015;35:997-1007

DOI: 10.1159/000369755

Published online: February 02, 2015

Chen et al.: MiR-144 Inhibits Proliferation in Lung Cancer Cells

\section{Results}

MiR-144 expression in lung cancer

To calculate relative miR-144 concentrations by fold changes $\left(2^{-\Delta \Delta \mathrm{Ct}}, \Delta \mathrm{Ct}\right.$ $=\mathrm{Ct}$ median miR-144 - Ct median GAPDH; $\Delta \Delta \mathrm{Ct}=\Delta \mathrm{Ct}$ cancer $-\Delta \mathrm{Ct}$ normal), we found that miR-144 expression was significantly lower in lung cancer tissues than in paired adjacent normal tissues $\left({ }^{*} P<0.05\right)$. The clinicopathological characteristics of the 67 lung cancer cases are presented in Table 1. Of the 67 lung cancer patients, miR-144 expression was related to tumor size $(<3 \mathrm{~cm}$ : $0.41 \pm 0.124$ vs. $>3 \mathrm{~cm}: 0.32 \pm 0.072,{ }^{*} P<0.01$ ,Table 1). And miR-144 expression level showed significant differences in various TNM ( ${ }^{*} P<0.01$, Table 1 ). MiR-144 expression was also lower in the lymph node metastasispositive group than the negative group $(0.31 \pm 0.069$ vs. $0.42 \pm 0.116$, respectively, $* P<0.01$, Table 1). While no significant differences were detected with CLPTM1L mRNA expression $(P>0.05$, Table 1 , Fig. $1 \mathrm{~F}$, J). No significant differences was observed between miR-144 expression and gender, age, smoking, differentiation or histology $(P$ $>0.05$, Table 1).
Table 1. Clinicopathological characteristics and miR144 expression levels of 67 lung cancer patients *Indicated statistical significance $(\mathrm{P}<0.05)$

\begin{tabular}{|c|c|c|c|}
\hline Clinicopathologic parameters & cases & miR-144 expression & $P$ value \\
\hline \multicolumn{4}{|l|}{ Gender } \\
\hline Male & 38 & $0.35 \pm 0.098$ & 0.173 \\
\hline Female & 29 & $0.39 \pm 0.126$ & \\
\hline \multicolumn{4}{|l|}{ Age(years) } \\
\hline$<50$ & 24 & $0.37 \pm 0.093$ & 0.853 \\
\hline$>50$ & 43 & $0.36 \pm 0.122$ & \\
\hline \multicolumn{4}{|l|}{ Smoking } \\
\hline Smoker & 24 & $0.37 \pm 0.107$ & 0.697 \\
\hline Non-smoker & 43 & $0.36 \pm 0.115$ & \\
\hline \multicolumn{4}{|l|}{ Tumor size } \\
\hline$<3 \mathrm{~cm}$ & 36 & $0.41 \pm 0.124$ & $0.001^{*}$ \\
\hline$>3 \mathrm{~cm}$ & 31 & $0.32 \pm 0.072$ & \\
\hline \multicolumn{4}{|l|}{ Differentiation } \\
\hline well & 28 & $0.38 \pm 0.116$ & 0.651 \\
\hline moderate & 25 & $0.37 \pm 0.122$ & \\
\hline poor & 14 & $0.34 \pm 0.083$ & \\
\hline \multicolumn{4}{|l|}{ Histology } \\
\hline Squamous carcinoma & 24 & $0.35 \pm 0.121$ & 0.463 \\
\hline Adinocarcinoma & 36 & $0.38 \pm 0.109$ & \\
\hline Others & 7 & $0.33 \pm 0.094$ & \\
\hline \multicolumn{4}{|l|}{ TNM } \\
\hline 1 & 25 & $0.44 \pm 0.132$ & $0.000^{*}$ \\
\hline II\&III & 42 & $0.33 \pm 0.072$ & \\
\hline \multicolumn{4}{|l|}{ Lymphnode status } \\
\hline negative & 35 & $0.42 \pm 0.116$ & $0.000^{*}$ \\
\hline positive & 32 & $0.31 \pm 0.069$ & \\
\hline
\end{tabular}

Upregulation of miR-144 inhibits proliferation of A549 and H460 cells

Expression of miRNA-144 and TIGAR after transfection in A549 and H460 cells is shown in Fig. 1A and 1B. Compared to the scramble group and blank group, miR-144 expression levels of miR-144 group were significantly higher in A549 and H460 cells, and TIGAR expression levels were significantly lower in the miR-144 group $\left({ }^{*} P<0.05\right.$, Fig.1A, 1B). Cell growth curves are presented in Fig. 1C. There were no significant differences in $\mathrm{OD}_{490}$ values between the blank and scramble groups $(P>0.05)$. Compared with the blank and scramble groups, the $\mathrm{OD}_{490}$ values for the miR-144 group at48, 72 and $96 \mathrm{~h}$ were all significantly decreased $\left({ }^{*} P<0.05\right)$ in A549 (Fig. 1C) and H460 (Fig. 1D) cells. Colony formation in the miR-144 group was lower than in the scramble and blank groups for A549 and H460 cells $(* P<0.05$, Fig. $1 \mathrm{E}, 1 \mathrm{~F})$. The result remains coordinate in tumor heterotransplantation experiment that the tumor volumes of miR-144 group cells were relatively lower than scramble group and blank group $(* P<0.05$, Fig. $1 \mathrm{G}, 1 \mathrm{H})$.

\section{Upregulation of miR-144 enhances apoptosis of A549and H460 cells}

Flow cytometry indicated that the apoptosis rate in the miR-144 group was higher than in the scramble and blank groups for both A549 and H460 cells $\left({ }^{*} P<0.05\right.$, Fig. 2A, 2B). Caspase 3/7 activity in miR-144 group was higher than in the scramble and blank groups for A549 and H460 cells, which also indicated that apoptosis rate in the miR-144 group was increased compared to the other groups $\left({ }^{*} P<0.05\right.$, Fig. $\left.2 \mathrm{C}, 2 \mathrm{D}\right)$. In the Hoechst 33342 staining assay, similar results were observed by fluorescence microscopy for both A549 and H460 cells $(* P<0.05$, Fig. $2 \mathrm{E}, 2 \mathrm{~F})$.

Upregulation of miR-144 enhances autophagy of A549 and H460 cells

MDC staining was visualized by fluorescence microscopy. The number of autophagicvacuoles was increased in the miR-144 group compared to the scramble and 


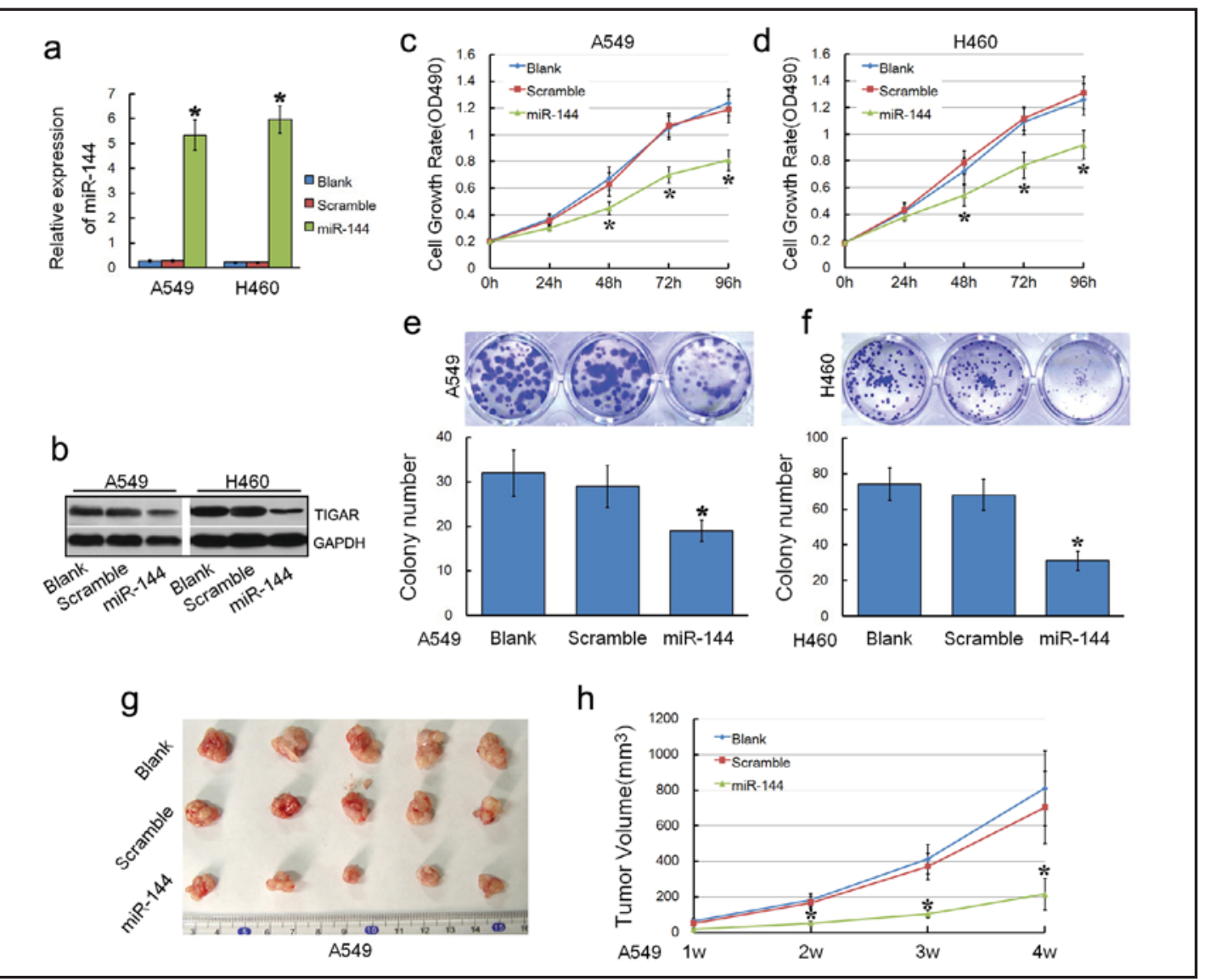

Fig. 1. miR-144 inhibits the proliferation level of A549 and H460 cells. (A, B) Compared to the scramble group and blank group in both A549 and H460 cells, the expression level of miR-144 was significantly higher and TIGAR was significantly lower in miR-144 group $\left({ }^{*} P<0.05\right)$. (C, D) The cell growth rate $\left(\mathrm{OD}_{490}\right)$ of miR-144 group goes slower than scramble group and blank group both A549 and H460 cells. (E, F) After approximately 2 weeks of incubation, the colony formation number of miR-144 group cells came to lower colony than the scramble group and blank group in both A549 and H460 cells ( $\left.{ }^{*} P<0.05\right)$. (G, H) G: The tumor tissues were collected from athymic nude mouse after four weeks. $\mathrm{H}$ : The tumor volumes were measured every week. The tumor volumes of miR group cell were relatively lower than scramble group and blank group $\left({ }^{*} P<0.05\right)$.

blank groups $\left({ }^{*} P<0.05\right.$, Fig. 3A). In addition, LC3 I, LC3 II and Beclin 1 , the markers of autophagic vacuoles, were detected by Western blotting. Compared to the scramble and blank groups, the relative expression levels of LC3 I protein in A549 and H460 cells was lower in the miR-144 group cells, and Beclin1 and LC3 II proteins were higher $\left({ }^{*} P<0.05\right.$, Fig. 3B, 3C). These results indicated that upregulation of miR-144 can enhance autophagy of A549 and $\mathrm{H} 460$ cells.

\section{TIGAR is a direct target of miR-144}

Bioinformatics analysis predicted that the 3' UTRs of TIGAR contained binding sites for miR-144 (Fig. 4A). Both wild-type and mutant TIGAR 3' UTRs were shown in Fig. 4B. Cotransfection with miR-144 significantly suppressed luciferase activity of the reporter containing the wild-type 3 ' UTR $\left({ }^{*} P<0.05\right.$, Fig. 4C). Our results indicate that miR-144 negatively regulates TIGAR expression by directly binding to putative binding sites in the 3' UTR. 


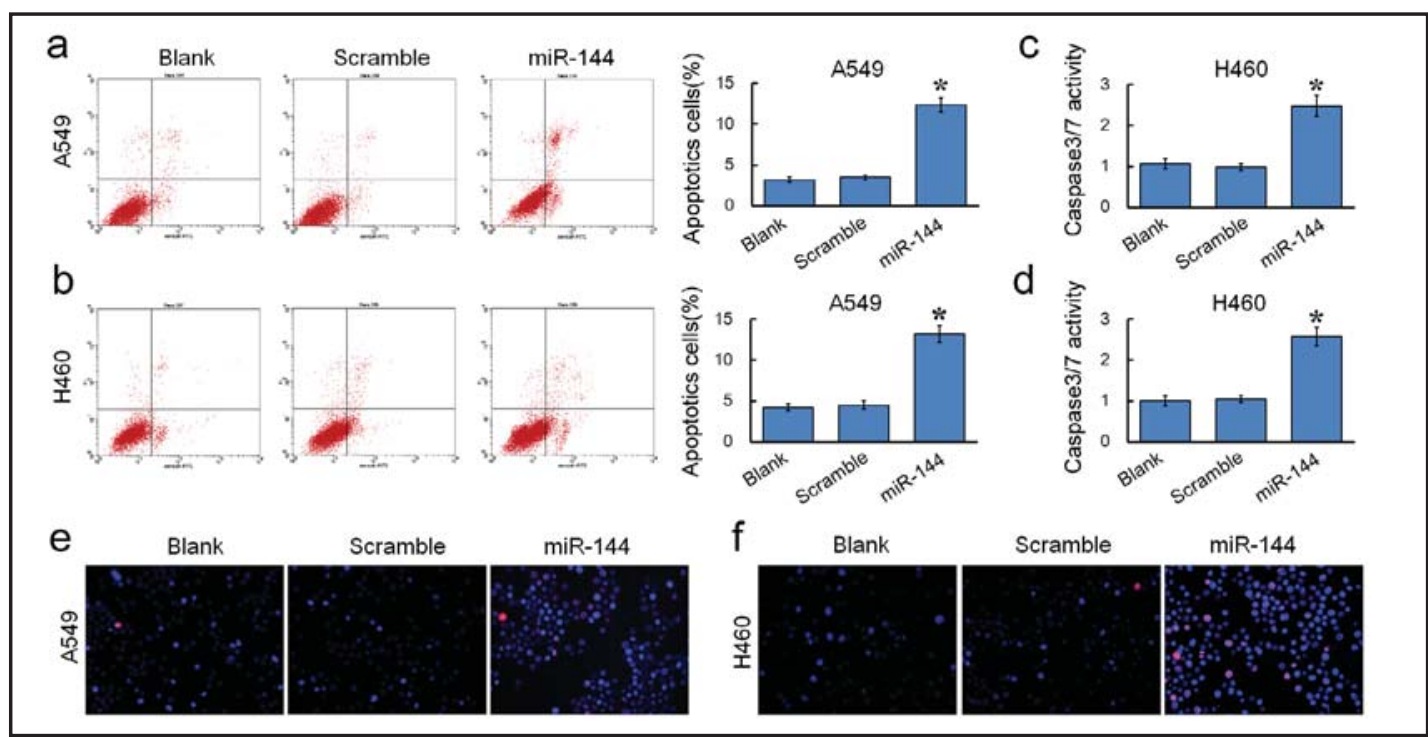

Fig. 2. miR-144 enhances the apoptosis rate of A549 cells and H460 cells. (A, B) Apoptosis rate in miR-144 group was higher than scramble group and blank group in A549 and H460 cells $\left({ }^{*} P<0.05\right)$. (C, D) Caspase3/7 activity of miR-144 group went higher than that of scramble and blank group in A549 and H460 cells $\left({ }^{*} P<0.05\right)$. (E, F) The hoechst 33342 staining assay come out that the apoptosis rate was higher in miR-144 group than the scramble group and blank group $\left({ }^{*} P<0.05\right)$.

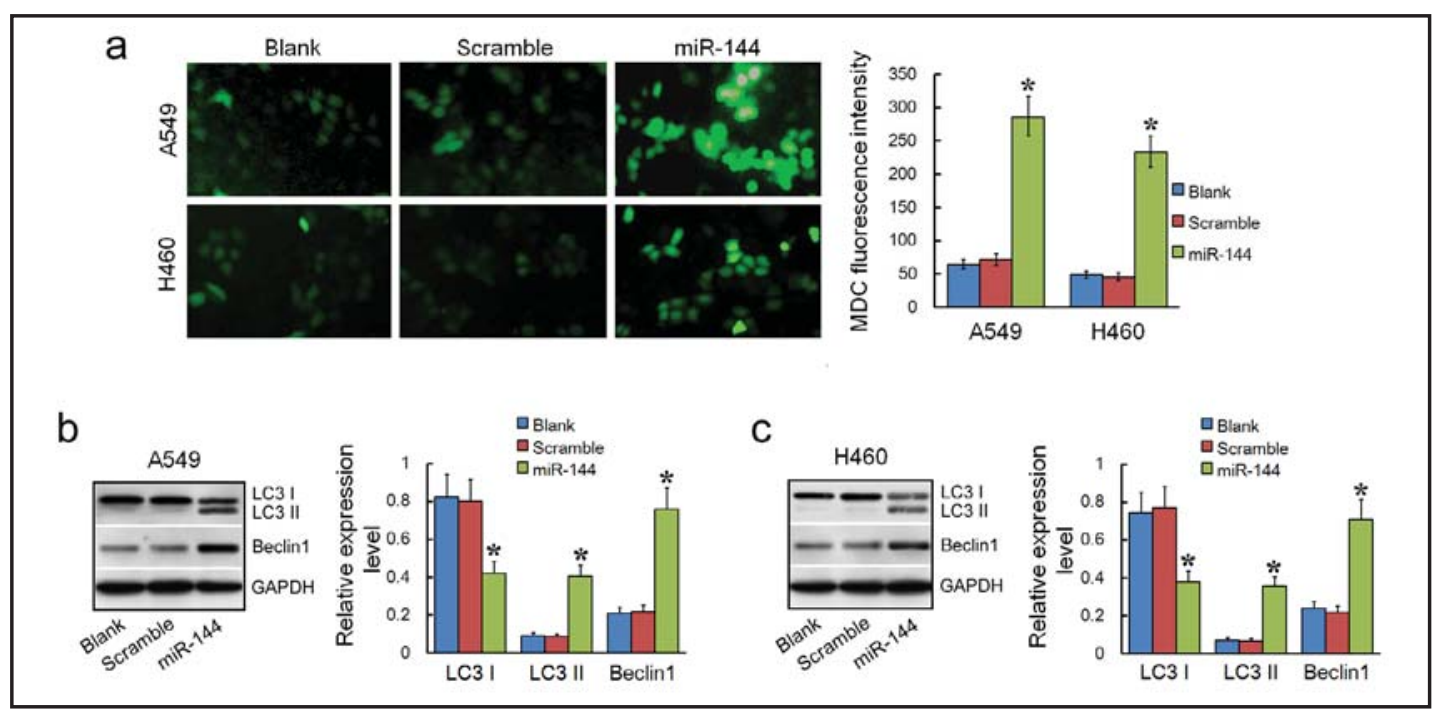

Fig. 3. miR-144 induces autophagy in both A549 and H460 cells. (A) Autophagic vacuoles of miR-144 group are much more than the scramble and blank group $(* P<0.05)$. (B, C) The expressions of autophagy-related proteins were detected by Western blotting. GAPDH was used as control. In both A549 and H460 cells, the expression levels of LC3-I was lower, and Beclin 1 and LC3-II came out higher in miR-144 groups $\left({ }^{*} P<0.05\right)$.

\section{Function of miR-144 inA549 cells partially attributed to targeting TIGAR}

We constructed si-TIGAR vector and transfected it into A549 cells (si-TIGAR group). By western blotting, we observed that expression of TIGAR protein in the si-TIGAR group was lower than in the miR-144 and blank group cells, and Beclin1 and LC3 II proteins were higher in A549 cells (Fig. 5A).The $\mathrm{OD}_{490}$ values of the si-TIGAR groupat48, 72 and $96 \mathrm{~h}$ were significantly decreased compared with the blank group cells, but increased compared with the miR-144 group cells $\left({ }^{*} P<0.05\right.$,Fig. $\left.5 \mathrm{~B}\right)$.The number of colonies in the si-TIGAR group was significantly lower than in the blank group, but higher than in the miR-144 group (Fig. 

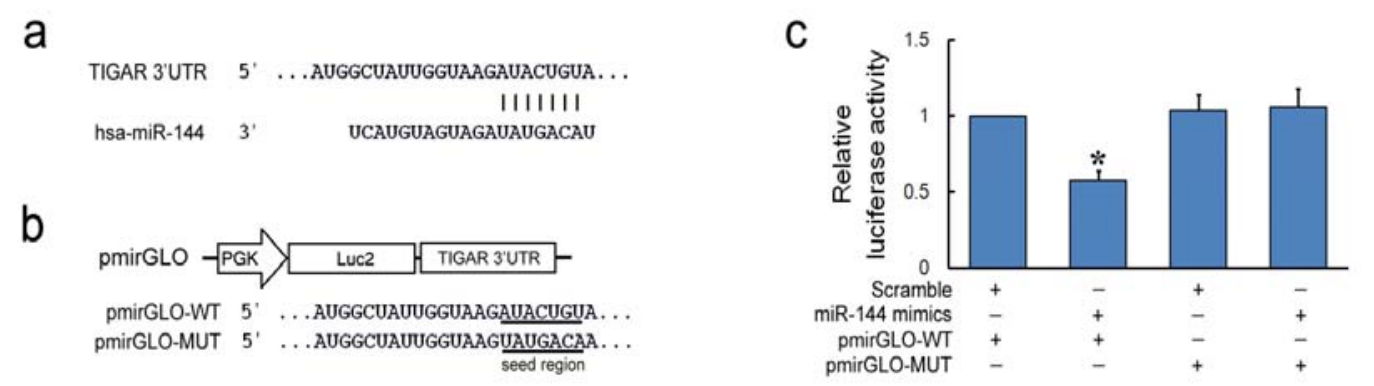

Fig. 4. miR-144 directly targets TIGAR. (A, B) Wild and mutant types of TIGAR 3'UTRs segments are showed. (C) Co-transfection with miR-144 significantly suppressed the luciferase activity of the reporter containing the wild-type 3 ' UTR $\left({ }^{*} P<0.05\right)$.

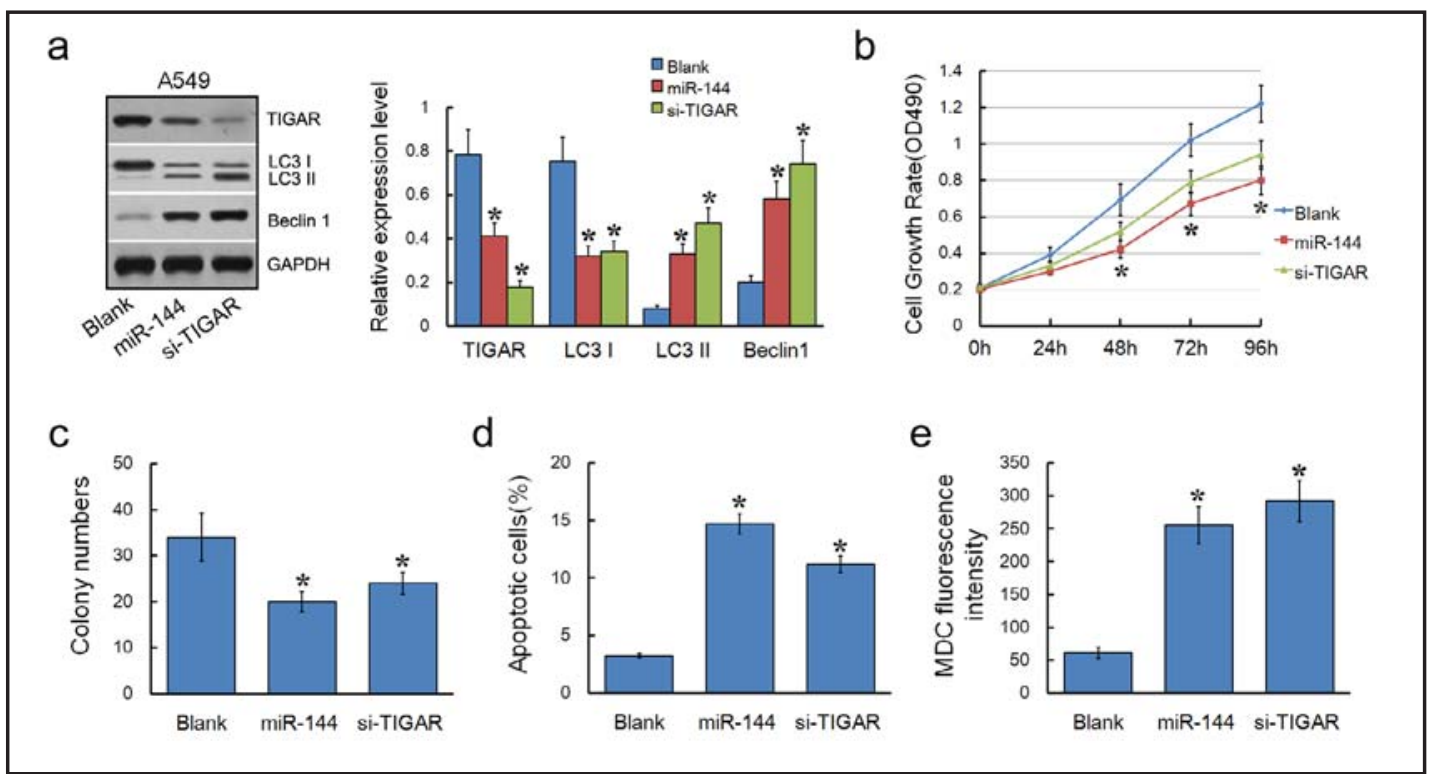

Fig. 5. Function of miR-144 partially attributes to targeting at TIGAR. (A) The expression of TIGAR protein of si-TIGAR group was lower than miR-144 and blank group cells, and Beclin1 and LC3 II proteins came out higher in A549 cell $\left({ }^{*} P<0.05\right)$. (B) The $\mathrm{OD}_{490}$ values of si-TIGAR group on $48 \mathrm{~h}, 72 \mathrm{~h}$ and $96 \mathrm{~h}$ were significantly decreased than blank group cell, but increased than miR-144 group $\left({ }^{*} P<0.05\right)$. (C) The colony numbers of si-TIGAR group was significantly decreased than blank group cell, but increased than miR-144 group $\left({ }^{*} P<0.05\right)$. (D) Apoptotic cells of si-TIGAR group was significantly increased than blank group cell, but decreased than miR-144 group $\left({ }^{*} P<0.05\right)$. (E) MDC fluorescence intensity of si-TIGAR group was higher than both blank and miR-144 group cells $\left({ }^{*} P<0.05\right)$.

5C). The number of apoptotic cells in the si-TIGAR group was significantly higher than in the blank group, but lower than in the miR-144 group $\left({ }^{*} P<0.05\right.$, Fig. 5D). MDC fluorescence intensity of the si-TIGAR group was higher than in the blank and miR-144 groups $\left({ }^{*} P<0.05\right.$, Fig. 5E). While these results indicate that the functions of TIGAR and miR-144 in A549 cells are largely similar, their degree of function to A549 cell is somewhat inconsistent which supports that the function of miR-144 in A549 cells is partially attributed to targeting TIGAR.

\section{Discussion}

MiRNAs are a class of small noncoding single-stranded RNA molecules that are found in plants, animals, and some viruses, which function in RNA silencing and post-transcriptional 


\section{Cellular Physiology and Biochemistry}

Cell Physiol Biochem 2015;35:997-1007

DOI: 10.1159/000369755

Publisned onIIne: February 02, 2015

Karger AG, Basel

www.karger.com/cpb

regulation of gene expression $[18,19]$. Most miRNAs exist as single copies, multiple copies or clusters in the genome, and most of them have a hairpin structure. miRNAs function via base pairing with complementary sequences within mRNA molecules [20-23], cutting off the mRNA molecule on target genes, or inhibiting translation of target genes. Some research has indicated that miR-144 is downregulated in many cancers [24-31]. These previous findings coincide with our results, which identified that miR-144 is significantly downregulated in human lung cancer. We found that altered miR-144 expression levels were associated with tumor size, TNM stage and lymph node metastasis in human lung cancer. We also identified that in lung cancer cell lines (A549 and H460 cells), proliferation was inhibited, and apoptosis and autophagy were enhanced after transfection with miR-144 mimics. These results imply that miR-144 acts as an inhibitor of lung cancer, and that it contributes to the development, progression and metastasis of lung cancer.

Autophagy is a catabolic process that is correlated with various physiological procedures and pathological conditions including cancer. It refers to the degradation of unnecessary cells or dysfunctional organelles using lysosomes [32-35]. In the autophagic process, LC3 I, a soluble form in the cytoplasm, transforms into LC3 II which localizes on the autophagosome membrane [36]. Another protein with a known role in mediating autophagy is Beclin 1 [37]. Its increased expression has been found to promote autophagy as well as inhibit the cell's tumor forming potential. Here, we observed that the levels of both LC3 II and Beclin 1 increased in miR-144 groups $(P<0.05)$. This may imply that miR-144 can regulated the autophagy ability of A549 and $\mathrm{H} 460$ cells, thus concerned with the occurrence and development of lung cancer.

Bioinformatics analysis using TargetScan and miRanda revealed that one target of miR144 was TIGAR (NM_020375), which lay within a cancer susceptibility locus on chromosome 12. TIGAR was discovered by microarray analysis of gene expression following activation of p53.TIGAR overexpression is observed in several types of tumor. Functions of TIGAR primarily manifest in lowering glycolysis, which results in the elimination of reactive oxygen species. All of these functions lead to less cell death, protection from apoptosis, and inhibition of autophagy. TIGAR affects the development of different types of tumors. For instance, in nasopharyngeal cancer cells, inhibition ofc-Met, a tyrosine kinase whose overexpression is associated with poor survival and metastasis [38], results in lower expression of TIGAR and increased cell death [39]. Also, knockdown of TIGAR by RNA interference induces apoptosis in HepG2 hepatocellular carcinoma cells; expression of TIGAR can affect the balance between cell growth and death; and TIGAR modulation influences apoptosis and autophagy in HepG2 cells [40]. To further confirm that TIGAR was one of the direct functional targets of miR-144, the $3^{\prime}$ UTR region of TIGAR was amplified from human genomic DNA and inserted into the pmirGLO vector to construct a luciferase reporter plasmid, and qRT-PCR, western blotting, luciferase reporter and knockdown assays were performed. The CCK-8 assay, colony formation assay, flow cytometry assay, caspase $3 / 7$ activity assay and MDC staining results demonstrated that silencing TIGAR had similar functional effects as enhanced expression of miR-144. These results indicated that miR-144 might act as a metastasis suppressor by targeting TIGAR.

In conclusion, we showed that miR-144 expression is lower in human lung cancer. We also showed that in lung cancer cell lines (A549 and H460 cells), upregulation of miR-144 inhibited proliferation and promoted apoptosis and autophagy. Based on these findings, we propose that miR-144 might be used as a therapeutic agent against lung cancer.

\section{Acknowledgements}

This study was supported by the Ministry of Major Science and Technology of Henan (201302005).

\section{Disclosure Statement}

None

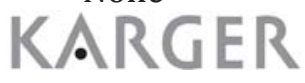




\section{Cellular Physiology and Biochemistry}

Cell Physiol Biochem 2015;35:997-1007

\begin{tabular}{l|l}
\hline DOI: $10.1159 / 000369755$ & (c) 2015 S. Karger AG, Basel
\end{tabular}

www.karger.com/cpb

Chen et al.: MiR-144 Inhibits Proliferation in Lung Cancer Cells

\section{References}

1 Ambros V: microRNAs: tiny regulators with great potential. Cell 2001;107:823-826

2 Iorio MV, Croce CM: Causes and consequences of microRNA dysregulation. Cancer J 2012;18:215-222.

- 3 Esquela-Kerscher A, Slack FJ: Oncomirs - microRNAs with a role in cancer. Nat Rev Cancer 2006;6:259-269.

4 Wang XC, Tian LL, Jiang XY, Wang YY, Li DG, She Y, Chang JH, Meng AM: The expression and function of miRNA-451 in non-small cell lung cancer. Cancer Lett 2011;311:203-209.

-5 Zhang LY, Ho-Fun Lee V, Wong AM, Kwong DL, Zhu YH, Dong SS, Kong KL, Chen J, Tsao SW, Guan XY, Fu L: MicroRNA-144 promotes cell proliferation, migration and invasion in nasopharyngeal carcinoma through repression of PTEN. Carcinogenesis 2013;34:454-463.

-6 Sureban SM, May R, Lightfoot SA, Hoskins AB, Lerner M, Brackett DJ, Postier RG, Ramanujam R, Mohammed A, Rao CV, Wyche JH, Anant S, Houchen CW: DCAMKL-1 regulates epithelial-mesenchymal transition in human pancreatic cells through a miR-200a-dependent mechanism. Cancer Res 2011;71:2328-2338.

7 Lan F, Yue X, Ren G, Li H, Ping L, Wang Y, Xia T: miR-15a/16 Enhances Radiation Sensitivity of Non-Small Cell Lung Cancer Cells by Targeting the TLR1/NF-кB Signaling Pathway. Int J Radiat Oncol Biol Phys DOI: 10.1016/j.ijrobp.2014.09.021.

8 Zha W, Cao L, Shen Y, Huang M: Roles of Mir-144-ZFX pathway in growth regulation of non-small-cell lung cancer. PLoS One 2013;8:e74175.

-9 Jen KY, Cheung VG: Identification of novel p53 target genes in ionizingradiation response. Cancer Res 2005;65:7666-7673.

10 Bensaad K, Cheung EC, Vousden KH: Modulation of intracellular ROS levels by TIGAR controls autophagy. EMBO J 2009;28:3015-3026.

11 Bensaad K, Tsuruta A, Selak MA, Vidal MN, Nakano K, Bartrons R, Gottlieb E, Vousden KH: TIGAR, a p53inducible regulator of glycolysis and apoptosis. Cell 2006;126:107-120.

-12 Cheung EC, Athineos D, Lee P, Ridgway RA, Lambie W, Nixon C, Strathdee D, Blyth K, Sansom OJ, Vousden KH: TIGAR is required for efficient intestinal regeneration and tumorigenesis. Dev Cell 2013;25:463-477.

13 Won KY, Lim SJ, Kim GY, Kim YW, Han SA, Song JY, Lee DK: Regulatory role of p53 in cancer metabolism via SCO2 and TIGAR in human breast cancer. Hum Pathol 2012;43:221-228.

14 Wanka C, Steinbach JP, Rieger J: Tp53-induced glycolysis and apoptosis regulator (TIGAR) protects glioma cells from starvation-induced cell death by up-regulating respiration and improving cellular redox homeostasis. J Biol Chem 2012;287:33436-33446.

-15 Network TC: Corrigendum: Comprehensive genomic characterization defines human glioblastoma genes and core pathways. Nature 2013;494:506.

16 Lewis BP, Burge CB, Bartel DP: Conserved seed pairing, often flanked by adenosines, indicates that thousands of human genes are microRNA targets. Cell 2005;120:15-20.

17 Enright AJ, John B, Gaul U, Tuschl T, Sander C, Marks DS: MicroRNA targets in Drosophila. Genome Biol 2003;5:R1.

18 Ambros V: The functions of animal microRNAs. Nature 2004;431:350-355.

19 Bartel DP: MicroRNAs: genomics, biogenesis, mechanism, and function. Cell 2004;116:281-297.

20 Bartel DP: MicroRNAs: target recognition and regulatory functions. Cell 2009;136:215-233.

21 Brennecke J, Cohen SM: Towards a complete description of the microRNA complement of animal genomes. Genome Biol 2003;4:228.

22 Calin GA, Croce CM: MicroRNA signatures in human cancers. Nat Rev Cancer 2006;6:857-866.

23 Chan JA, Krichevsky AM, Kosik KS: MicroRNA-21 is an antiapoptotic factor in human glioblastoma cells. Cancer Res 2005;65:6029-6033.

24 Zhao M, Huang J, Gui K, Xiong M, Cai G, Xu J, Wang K, Liu D, Zhang X, Yin W: The downregulation of miR144 is associated with the growth and invasion of osteosarcoma cells through the regulation of TAGLN expression. Int J Mol Med 2014;34:1565-1572.

25 Cao T, Li H, Hu Y, Ma D, Cai X: miR-144 suppresses the proliferation and metastasis of hepatocellular carcinoma by targeting E2F3.Tumour Biol 2014;35:10759-10764.

26 Guan H, Liang W, Xie Z, Li H, Liu J, Liu L, Xiu L, Li Y: Down-regulation of miR-144 promotes thyroid cancer cell invasion by targeting ZEB1 and ZEB2. Endocrine DOI 10.1007/s12020-014-0326-7. 
-27 Hu YW, Hu YR, Zhao JY, Li SF, Ma X, Wu SG, Lu JB, Qiu YR, Sha YH, Wang YC, Gao JJ, Zheng L, Wang Q: An agomir of miR-144-3p accelerates plaque formation through impairing reverse cholesterol transport and promoting pro-inflammatory cytokine production. PLoS One 2014;9:e94997.

28 Fu X, Huang X, Li P, Chen W, Xia M: 7-Ketocholesterol inhibits isocitrate dehydrogenase 2 expression and impairs endothelial function via microRNA-144. Free Radic Biol Med 2014;71:1-15.

29 Ding H, Wu YL, Wang YX, Zhu FF: Characterization of the microRNA expression profile of cervical squamous cell carcinoma metastases. Asian Pac J Cancer Prev 2014;15:1675-1679.

- 30 Liang Y, Lin Q, Luo F, Wu W, Yang T, Wan S: Requirement of miR-144 in CsA induced proliferation and invasion of human trophoblast cells by targeting titin. J Cell Biochem 2014;115:690-696.

- 31 Su Z, Si W, Li L, Zhou B, Li X, Xu Y, Xu C, Jia H, Wang QK: MiR-144 regulates hematopoiesis and vascular development by targeting meis1 during zebrafish development. Int J Biochem Cell Biol 2014;49:53-63.

- 32 Lin NY, Beyer C, Gießl A, Giessl A, Kireva T, Scholtysek C, Uderhardt S, Munoz LE, Dees C, Distler A, Wirtz S, Krönke G, Spencer B, Distler O, Schett G, Distler JH: Autophagy regulates TNF $\alpha$-mediated joint destruction in experimental arthritis. Ann Rheum Dis 2012;72:761-768.

33 Klionsky DJ: Autophagy revisited: A conversation with Christian de Duve. Autophagy 2008;4:740-743.

- 34 Peracchio C, Alabiso O, Valente G, Isidoro C: Involvement of autophagy in ovarian cancer: a working hypothesis. J Ovarian Res 2012;5:22.

-35 Patel AS, Lin L, Geyer A, Haspel JA, An CH, Cao J, Rosas IO, Morse D: Autophagy in idiopathic pulmonary fibrosis. PLoS One 2012;7:e41394.

-36 Yu C, Wang L, Lv B, Lu Y, Zeng L, Chen Y, Ma D, Shi T, Wang L: TMEM74, a lysosome and autophagosome protein, regulates autophagy. Biochem Biophys Res Commun 2008;369:622-629.

-37 Wang ZH, Xu L, Duan ZL, Zeng LQ Yan NH, Peng ZL: Beclin 1-mediated macroautophagy involves regulation of caspase-9 expression in cervical cancer HeLa cells. Gynecol Oncol 2007;107:107-113.

-38 Comoglio PM, Giordano S, Trusolino L: Drug development of MET inhibitors: targeting oncogene addiction and expedience. Nat Rev Drug Discov 2008;7:504-516.

39 Lui VW, Wong EY, Ho K, Ng PK, Lau CP, Tsui SK, Tsang CM, Tsao SW, Cheng SH, Ng MH, Ng YK, Lam EK, Hong B, Lo KW, Mok TS, Chan AT, Mills GB: Inhibition of c-Met downregulates TIGAR expression and reduces NADPH production leading to cell death. Oncogene 2011;30:1127-1134.

40 Ye L, Zhao X, Lu J, Qian G, Zheng JC, Ge S: Knockdown of TIGAR by RNA interference induces apoptosis and autophagy in HepG2 hepatocellular carcinoma cells. Biochem Biophys Res Commun 2013;437:300-306. 